\title{
Ubiquitin-proteasome-dependent proteolysis in skeletal muscle
}

\author{
Didier Attaix*, Eveline Aurousseau, Lydie Combaret, \\ Anthony Kee, Daniel Larbaud, Cécile Rallière, \\ Bertrand Souweine, Daniel Taillandier, Thomas Tilignac
}

\author{
Centre de recherche en nutrition humaine de Clermont-Ferrand \\ et Inra, Theix, 63122 Ceyrat, France
}

(Received 26 February 1998; accepted 2 March 1998)

\begin{abstract}
The ubiquitin-proteasome proteolytic pathway has recently been reported to be of major importance in the breakdown of skeletal muscle proteins. The first step in this pathway is the covalent attachment of polyubiquitin chains to the targeted protein. Polyubiquitylated proteins are then recognized and degraded by the $26 \mathrm{~S}$ proteasome complex. In this review, we critically analyse recent findings in the regulation of this pathway, both in animal models of muscle wasting and in some human diseases. The identification of regulatory steps of ubiquitin conjugation to protein substrates and/or of the proteolytic activities of the proteasome should lead to new concepts that can be used to manipulate muscle protein mass. Such concepts are essential for the development of anti-cachectic therapies for many clinical situations. (O) Inra/Elsevier, Paris
\end{abstract}

skeletal muscle / protein breakdown / ubiquitin / proteasome

Résumé - Protéolyse musculaire ubiquitine-protéasome dépendante. Il a été récemmment démontré que la protéolyse ubiquitine-protéasome dépendante joue un rôle majeur dans la dégradation des protéines musculaires. La première étape de cette voie protéolytique correspond à la fixation covalente de chaînes polyubiquitylées sur les substrats protéiques. Ces protéines polyubiquitylées sont ultérieurement spécifiquement reconnues et dégradées par le protéasome $26 \mathrm{~S}$. Les derniers progrès accomplis dans la compréhension de la régulation de ce système dans les modèles animaux de fontes protéiques musculaires, et dans certaines situations cliniques, sont analysés de façon critique dans cette revue bibliographique. L'identification d'étapes régulatrices de l'ubiquitylation des substrats protéiques, et/ou des activités protéolytiques du protéasome, devrait conduire à de nouveaux concepts utilisables pour manipuler le dépôt des protéines musculaires. En particulier, ces concepts sont indispensables au développement de traitements anti-cachectiques dans de nombreuses situations cliniques. (C) Inra/Elsevier, Paris

muscle squelettique / protéolyse / ubiquitine / protéasome

* Correspondence and reprints

E-mail: attaix@clermont. inra.fr 


\section{INTRODUCTION}

Proteins in skeletal muscle, as in other mammalian tissues, undergo a continuous process of synthesis and degradation, which regulates the levels of specific proteins and the overall muscle protein mass [46]. For example, increased proteolysis contributes to the muscle wasting seen with fasting and several pathological conditions. In such states, enhanced protein breakdown in skeletal muscle, the major protein reservoir in the body, is a key metabolic adaptation providing the organism with free amino acids for energy production via increased gluconeogenesis and direct oxidation. In some instances, for example in sepsis, net mobilization of muscle protein also provides free amino acids for acute phase protein synthesis in the liver.

The lysosomal, $\mathrm{Ca}^{2+}$-activated and ubiquitin-proteasome-dependent pathways are the three major proteolytic processes widely believed to be responsible for the breakdown of proteins in skeletal muscle $[1,2]$. In recent years, it has become apparent that both lysosomal and $\mathrm{Ca}^{2+}$-activated proteases (i.e. cathepsins and calpains, respectively) do not play a major role in this tissue: they contribute less than 15-20\% of total protein breakdown in muscles from control and cachectic animals, and are not responsible for the breakdown of myofibrillar proteins [15, 25, 41]. Furthermore, a systematic activation of either cathepsins or calpains has not been observed in several instances of muscle atrophy (see Attaix and Taillandier [1] for detailed information). By contrast, the activation of the ubiquitin-proteasome pathway is mainly responsible for the muscle wasting that prevails in various animal models of cachexia, as well as in some human diseases [1, 2, 29]. In this paper we critically review the evidence that this pathway is the major proteolytic process in skeletal muscle. We also discuss the impli- cations of this information for the development of new strategies designed to prevent muscle wasting.

\section{THE UBIQUITIN-PROTEASOME PATHWAY}

Ubiquitin is an abundant highly conserved 76-residue polypeptide, which seems to be present in all eukaryotic cells. The first step in the ubiquitin-proteasome pathway is the covalent attachment of polyubiquitin chains to the targeted protein (figure 1). Ubiquitin is first activated in the presence of ATP to a high energy thiol ester intermediate by the ubiquitin-activating enzyme (E1). Following activation, ubiquitin-conjugating enzymes (E2s) transfer ubiquitin from E1 to ubiquitinprotein ligases (E3s). In turn, E3s covalently bind ubiquitin to protein substrates via an isopeptide bond between the activated $C$-terminal residue of ubiquitin and $\varepsilon$-amino groups of lysine residues in protein substrates (see Haas and Siepmann [18] for a recent review). E3s play a role in the selection of proteins for conjugation and catalyse the formation of polyubiquitin chains on the target protein, which are recognized as a degradation signal by the $26 \mathrm{~S}$ proteasome (figure 1). It should be noted that E2s can directly transfer ubiquitin to some protein substrates (typically basic proteins such as histones) in the absence of E3. However, in this case, most of the conjugates formed are monoubiquitylated proteins, which are usually not targeted for degradation.

The second step in the ubiquitin-proteasome pathway is the degradation of polyubiquitylated proteins by the $26 \mathrm{~S}$ proteasome complex (figure 1). The $26 \mathrm{~S}$ proteasome is formed by the association of the $20 \mathrm{~S}$ proteasome with two $19 \mathrm{~S}$ regulatory complexes (see Coux et al. [9] and Baumeister et al. [7] for recent reviews). The $20 \mathrm{~S}$ proteasome is the core of the pro- 


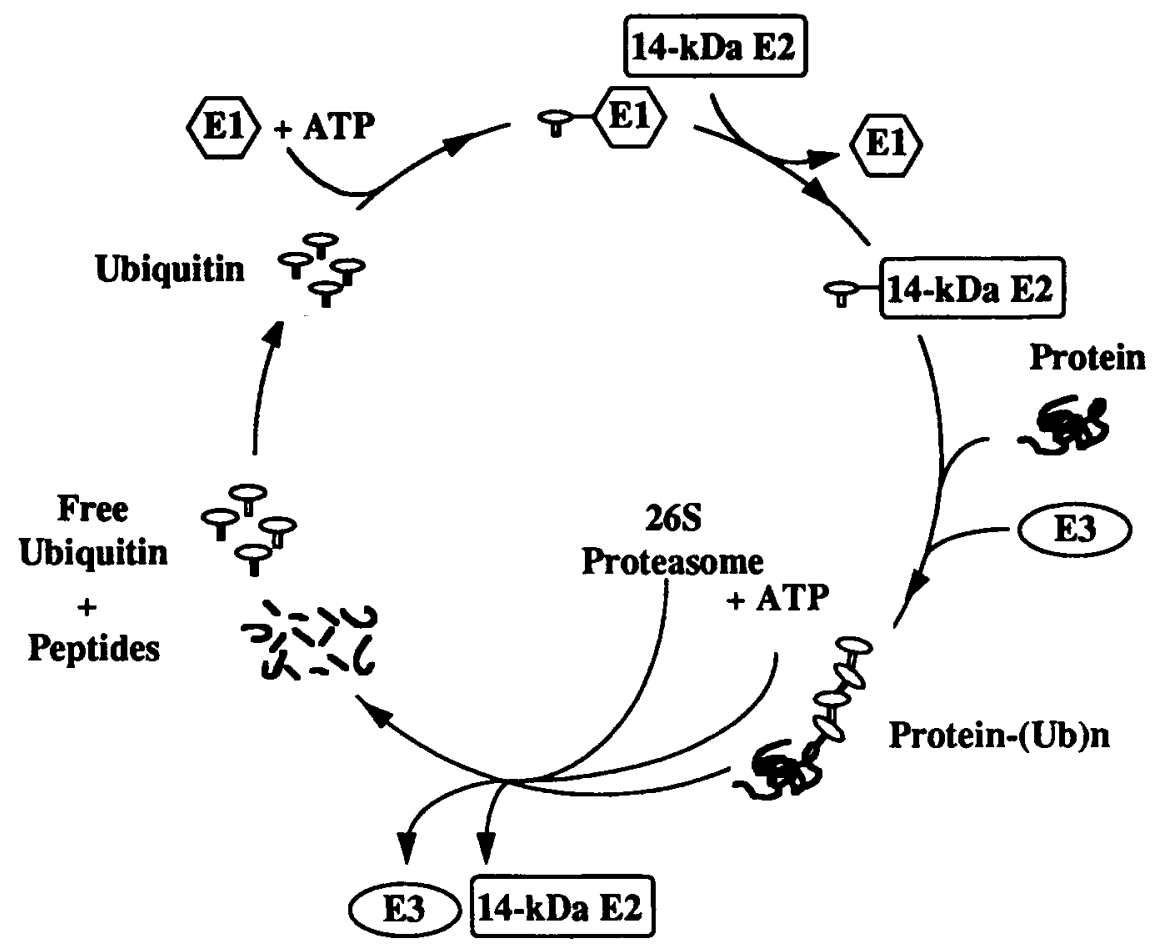

Figure 1. Schematic representation of the ubiquitin-proteasome pathway in skeletal muscle. E1: ubiquitin-activating enzyme; E2: ubiquitin-conjugating enzyme; E3: ubiquitin-protein ligase; Protein-(Ub)n: polyubiquitylated protein. Note that only the $14-\mathrm{kDa}$ E2 has been reported to be regulated in skeletal muscle (see text).

teolytic machinery. This barrel-shaped complex is organized as a stack of four rings, each ring having seven subunits ( figure 2 ). The non-catalytic $\alpha$-subunits form the two outer rings, and the catalytic $\beta$ subunits the two inner rings, the latter containing the active sites which are located inside the cylinder. Lobster muscle $20 \mathrm{~S}$ proteasome has been extensively studied, and contains five peptidase activities [31]. In vitro studies have shown that the branched chain amino acid-preferring, the peptidylglutamyl peptide hydrolase and trypsin-like activities are involved in the degradation of contractile proteins. Individual $19 \mathrm{~S}$ complexes bind to each of the outer $\alpha$-rings of the $20 S$ proteasome in the presence of ATP (figure 2). These 19S caps contain at least 18 different subunits. Six subunits are members of the AAAATPase family (ATPases associated with a variety of cellular activities). The ATPases are believed to provide energy for the assembly of the $26 \mathrm{~S}$ proteasome, the unfolding of protein substrates and possibly their injection into the catalytic chamber of the proteasome, and the breakdown of ubiquitylated proteins into peptides. The role of non-ATPase subunits is less clear, but presumably several subunits (including S5a [12]) recognize polyubiquitin chains and confer substrate specificity to the $26 \mathrm{~S}$ proteasome. However, it has been reported that the $26 \mathrm{~S}$ proteasome 


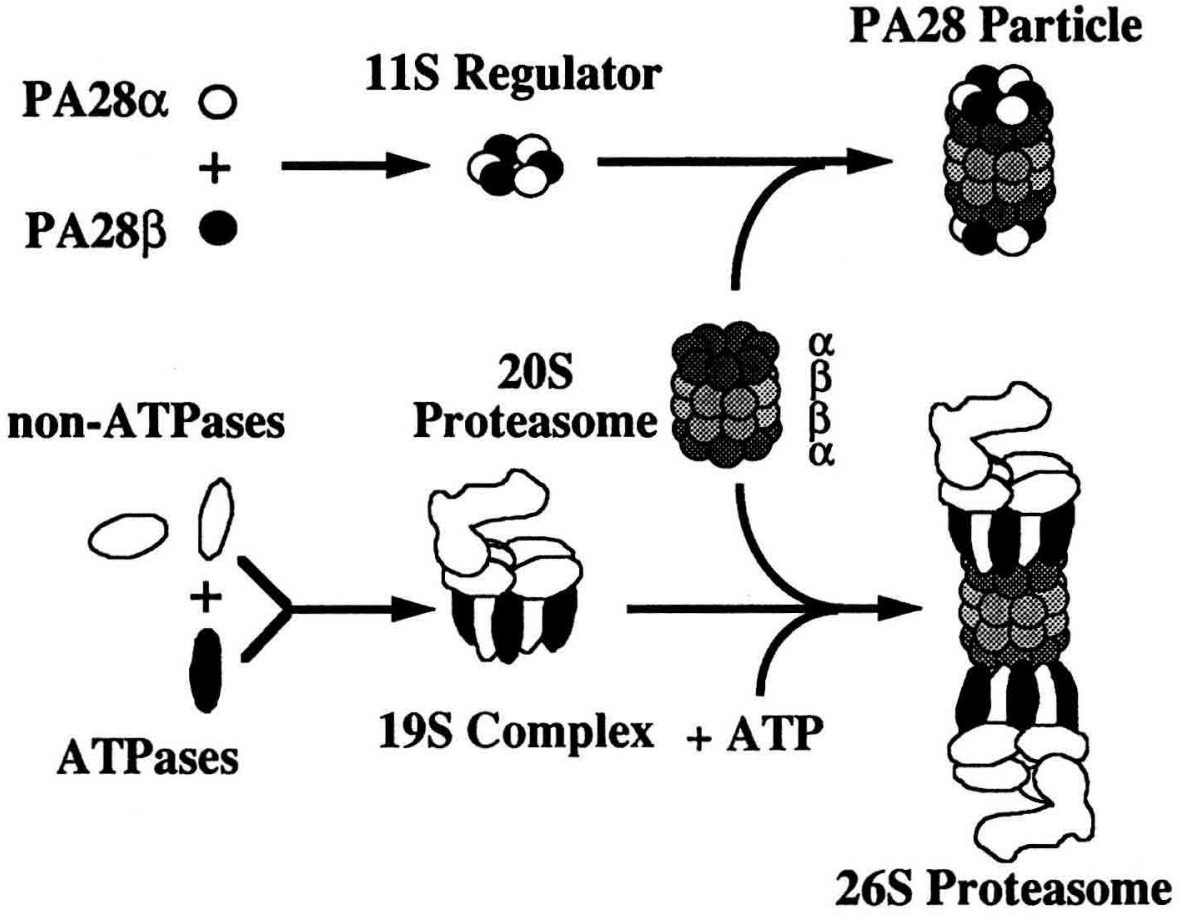

Figure 2. Schematic representation of the 20 S proteasome, PA28 particle and $26 \mathrm{~S}$ proteasome. $\alpha$ and $\beta$ denotes the $\alpha$ and $\beta$ subunits of the 20 S proteasome, respectively.

may also degrade non-ubiquitylated protein substrates (i.e. ornithine decarboxylase and the cytochrome P-450 family of enzymes). Whether or not the mammalian $26 \mathrm{~S}$ proteasome degrades ubiquitylated and/or non-ubiquitylated substrates in skeletal muscle to our knowledge has not been documented.

\section{REGULATION OF UBIQUITIN CONJUGATION IN SKELETAL MUSCLE}

\subsection{Ubiquitin expression}

Increased expression of skeletal muscle ubiquitin has been reported in several catabolic states in rodents (table I). This adaptation reflects increased transcription in at least acidosis [5] and diabetes [34], and seems to be specific to skeletal muscle. Increased ubiquitin mRNA levels were observed in both types I and II skeletal muscle fibers from starved rats, but not in liver, kidney and adipose tissue, which also undergo significant atrophy [28]. However, increased expression of ubiquitin was also reported in the heart [28] and intestines [37] of starved rats, and in skin from tumor-bearing animals [6]. It should be noted that high mRNA levels for ubiquitin do not systematically reflect increased protein breakdown in skeletal muscle. For example, old rats treated with dexamethasone exhibited increased ubiquitin expression, but rates of muscle proteolysis were 
Table I. Changes in the ubiquitin-conjugating system in various wasting conditions in rodents.

\begin{tabular}{lll}
\hline Proteolytic event & Wasting condition & \multicolumn{1}{c}{ Reference } \\
\hline Increased ubiquitin expression & Fasting & Wing and Goldberg [47] \\
& Cancer & Temparis et al. [40] \\
& Sepsis & Tiao et al. [41] \\
& Acidosis & Mitch et al. [30] \\
& Glucocorticoid treatment & Dardevet et al. [10] \\
& Denervation & Medina et al. [28] \\
& Burn injury & Fang et al. [14] \\
& Unweighting & Taillandier et al. [38] \\
& Diabetes & Price et al. [34] \\
& Interleukin-6 transgenic & Tsujinaka et al. [44] \\
& mice & \\
Increased 14-kDa E2 expression* & Fasting & Wing and Banville [48] \\
& Cancer & Temparis et al. [40] \\
& Glucocorticoid treatment & Dardevet et al. [10] \\
& Unweighting & Taillandier et al. [38] \\
& Sepsis & Voisin et al. [45] \\
& Cancer & Llovera et al. [23] \\
& Fasting, and Denervation & Wing et al. [50] \\
& Sepsis & Tiao et al. [42] \\
\hline
\end{tabular}

${ }^{*}$ Not consistently observed (see text).

not changed [10]. Although ubiquitin is a heat-shock protein, there was no coordinate increase in expression of other heatshock genes in the atrophying muscles from starved, denervated and cancer rats $[6,28]$. The precise mechanisms which result in increased ubiquitin expression have not been elucidated. However, there is increased production of glucocorticoids in several catabolic states [35, 42, 47], and glucocorticoid responsive elements have been detected in the promotors of the chicken and human polyubiquitin genes [4]. Ubiquitin expression is also regulated by insulin [22], and presumably indirectly by several cytokines including tumor necrosis factor- $\alpha$ (TNF- $\alpha)$ [24].

\subsection{Ubiquitin-activating enzyme, E1}

The sequence of E1 is highly conserved in several species. The human gene pos- sesses an alternative start codon, resulting in the expression of a 1058-residue nuclear form and a 1018-residue cytoplasmic form (see Haas and Siepmann [18]). $E_{1}$ has low expression in skeletal muscle [19]. However, its mRNA level was regulated in biopsies from acidotic patients with renal failure [36], and in atrophying muscles from hindlimb suspended rats (Taillandier and Attaix, unpublished observations).

\subsection{Ubiquitin-conjugating enzymes, E2s}

The ubiquitin-conjugating enzymes (or ubiquitin-carrier proteins), E2s, represent a superfamily of related proteins, with a molecular weight range of usually 14 to $35 \mathrm{kDa}$. To date, various E2 species have been found in skeletal muscle. These include the $14-, 17-$ and the $20-\mathrm{kDa}$ 
species. However, only the expression of the 14-kDa E2 was found to be regulated in muscle wasting [1]. The 14-kDa E2 has two transcripts (1.8 and $1.2 \mathrm{~kb}$ ) arising from different polyadenylation sites [48]. The 1.8-kb transcript, which corresponds to the major mRNA species in rat muscle, is barely detectable in humans [26] and goats [22]. The 1.2-kb transcript is tightly upregulated in various conditions of muscle atrophy in rats (table I) and humans [26]. Taillandier et al. [38] have shown that the increased mRNA levels for the 14-kDa E2, which occurred in the atrophying soleus muscle from unweighted rats, entered active translation. However, no increase in mRNA levels for the 14-kDa E2 was reported in the muscles from acidotic [33] or acutely septic [45] rats, although in both conditions the activation of a ubiquitin-dependent proteolytic process was responsible for increased proteolysis. Furthermore, increased expression of the 14-kDa E2 also does not always correlate with enhanced protein breakdown [40]. The expression of the $14-\mathrm{kDa} \mathrm{E} 2$ is regulated by glucocorticoids in adult rats, but not in old animals [10]. In vitro, insulin and insulin-like growth factor I decrease the stability of the $14-\mathrm{kDa}$ E2 mRNAs [49]. Such down-regulation, however, does not prevail in insulininfused animals [22].

\subsection{Ubiquitin-protein ligases, E3s}

There are at least six distinct E3s in mammalian cells. These enzymes play a role in the selection of substrates targeted for degradation by the ubiquitin-proteasome system (see Haas and Siepmann [18]). Unfortunately, very little is known about E3s in skeletal muscle, although the $14-\mathrm{kDa} \mathrm{E} 2$ is one of the major mammalian E2s that best supports E3-dependent conjugate formation and protein breakdown [20]. Gonen et al. [16] have reported that a very large $\mathrm{E} 3$, called E3L, is involved in the breakdown of some muscle proteins (actin, troponin $\mathrm{T}$ and MyoD). The degradation of these ubiquitylated proteins appears to be E2-F1dependent, a previously identified 'nonN-end-rule' E2, whereas the 14-kDa E2 is a ' $\mathrm{N}$-end rule' enzyme. Interestingly, Gonen et al. [16] also provided evidence that proteins can be conjugated and degraded by two distinct ubiquitin-dependent pathways. Lysozyme was conjugated either by $14-\mathrm{kDa} E 2$ and $\mathrm{E} 3 \alpha$ (i.e. recognized via its basic $\mathrm{N}$-terminal lysine residue, according to the ' $\mathrm{N}$-end rule'), or by the 'non- $\mathrm{N}$-end rule' pathway consisting of E2-F1 and E3L.

\subsection{Ubiquitin-protein conjugates}

During different catabolic conditions there is an increase in ubiquitin-protein conjugates in skeletal muscle (table I). These data strongly suggest that the degradation of ubiquitin-conjugates by the $26 \mathrm{~S}$ proteasome becomes rate-limiting in these catabolic states. However, other studies have given conflicting results. For example, no accumulation of ubiquitin-conjugates was observed in the muscles from septic [41] or tumor-bearing (Combaret and Attaix, unpublished observations) animals, even though a clear increase in ubiquitin expression occurs in such conditions $[40,41]$. In contrast, a decrease in ubiquitin-conjugates was observed during corticosterone treatment [4]. The reasons for such discrepancies are unclear, although it is conceivable that in some cases the changes in the levels of ubiquitin-conjugates may result from alteration in their rates of degradation. It has been observed that ubiquitylated proteins accumulate preferentially in the myofibrillar fraction [50], although others report conflicting findings [41]. Therefore, the proteins that are preferentially ubiquitylated in skele- 
tal muscle remain to be identified. It is noteworthy, however, that the levels of free ubiquitin in basal conditions are much higher than the dissociation constant for El, the enzyme involved in the first step of ubiquitylation [17]. Thus, it seems very unlikely that the amount of free muscle ubiquitin would become rate-limiting for conjugation. For example in one study, there was a dramatic decrease in ubiquitin expression in mixed skeletal muscles upon insulin treatment [22], without any change in the amount of ubiquitin-protein conjugates (Larbaud et al., unpublished observations).

\section{REGULATION OF THE PROTEASOME IN SKELETAL MUSCLE}

The enhanced proteolysis seen in various catabolic conditions is suppressed in ATP-depleted muscles (table II). This first indirect evidence strongly suggested that the proteasome is involved in the breakdown of muscle proteins. Furthermore, enhanced myofibrillar protein breakdown was also ATP-dependent (table II). Studies with ATP-depleted muscles were, however, not specific because skeletal muscle contains ATP-dependent but ubiquitin-

Table II. Changes in proteolytic events potentially related to the proteasome in various wasting conditions in rodents.

\begin{tabular}{|c|c|c|}
\hline Proteolytic events & Wasting condition & Reference \\
\hline $\begin{array}{l}\text { Increased total proteolysis blocked } \\
\text { by ATP depletion }\end{array}$ & $\begin{array}{l}\text { Denervation } \\
\text { Fasting } \\
\text { Cancer } \\
\text { Acidosis } \\
\text { Sepsis }\end{array}$ & $\begin{array}{l}\text { Medina et al. [27] } \\
\text { Wing and Goldberg [47] } \\
\text { Temparis et al. [40] } \\
\text { Mitch et al. [30] } \\
\text { Tiao et al. [41] }\end{array}$ \\
\hline $\begin{array}{l}\text { Increased myofibrillar proteolysis } \\
\text { blocked by ATP depletion }\end{array}$ & $\begin{array}{l}\text { Fasting } \\
\text { Sepsis }\end{array}$ & $\begin{array}{l}\text { Medina et al. [27] } \\
\text { Tiao et al. [41] }\end{array}$ \\
\hline $\begin{array}{l}\text { Increased total proteolysis blocked } \\
\text { by proteasome inhibitors }\end{array}$ & $\begin{array}{l}\text { Acidosis } \\
\text { Diabetes } \\
\text { Denervation, sepsis } \\
\text { and thyroid hormone } \\
\text { administration }\end{array}$ & $\begin{array}{l}\text { Bailey et al. [5] } \\
\text { Price et al. [34] } \\
\text { Tawa et al. [39] }\end{array}$ \\
\hline $\begin{array}{l}\text { Increased myofibrillar proteolysis } \\
\text { blocked by proteasome inhibitors }\end{array}$ & Sepsis & Hobler et al. [21] \\
\hline $\begin{array}{l}\text { Increased expression of } 20 \mathrm{~S} \\
\text { proteasome subunits }\end{array}$ & $\begin{array}{l}\text { Cancer } \\
\text { Acidosis } \\
\text { Glucocorticoid treatment } \\
\text { Fasting and denervation } \\
\text { Unweighting } \\
\text { Sepsis } \\
\text { Diabetes }\end{array}$ & $\begin{array}{l}\text { Temparis et al. [40] } \\
\text { Mitch et al. [30] } \\
\text { Dardevet et al. [10] } \\
\text { Medina et al. [28] } \\
\text { Taillandier et al. [38] } \\
\text { Voisin et al. [45] } \\
\text { Price et al. [34] }\end{array}$ \\
\hline $\begin{array}{l}\text { Changes in the expression of } 19 S \\
\text { complex subunits }\end{array}$ & Cancer and unweighting & Attaix et al. [3] \\
\hline
\end{tabular}


independent proteinases [13]. However, other experiments with specific inhibitors of the proteasome (e.g. peptidyl aldehydes and/or lactacystin) lead to identical interpretations. MG 132 (CBZ-leu-leuleucinal), a potent inhibitor of the branched chain amino acid-preferring, peptidylglutamyl peptide hydrolase and chymotryptic activities of the proteasome [9] was reported to block the activation of the ubiquitin-proteasome pathway in acidosis [5], diabetes [34], denervation, sepsis, and following administration of thyroid hormones [39]. More recently, Hobler et al. [21] observed that lactacystin (to date the most specific inhibitor of the proteasome) also blocks increased total and myofibrillar protein breakdown in septic rats.

The second piece of evidence that the proteasome is involved in the breakdown of muscle proteins is based on the increased expression of $20 \mathrm{~S}$ proteasome subunits that occurs in atrophying muscles (table II). In contrast with increased ubiquitin and 14-kDa E2 expression (see above), it is noteworthy that enhanced mRNA levels for $20 \mathrm{~S}$ proteasome subunits have been consistently observed only in muscles exhibiting high rates of protein breakdown $[10,40]$. Moreover, independent lines of evidence strongly suggest that these increased mRNA levels have some significance in catabolic states. First, an increased abundance of the 27$\mathrm{kDa} 20 \mathrm{~S}$ proteasome subunit correlates with enhanced expression of other subunits in cancer cachexia [6]. Indeed, there is an excellent correlation between mRNA levels for $20 \mathrm{~S}$ proteasome subunits and the amount of subunits detected by western blot analyses, not only in cancer, but also in various proteolytic conditions (Larbaud et al., unpublished observations). Second, Taillandier et al. [38] showed that the RC9 subunit enters active translation, when over-expressed in the atrophying muscles from unweighted rats. Finally, an increase in transcribed $\mathrm{RC} 3$ proteasome subunit mRNA is observed in acidosis [5]. There seems to be a transcriptional programme that favours increased expression of all $20 \mathrm{~S}$ proteasome subunits in muscle atrophy [29]. However, although upstream sequences of several $20 \mathrm{~S}$ proteasomal genes have been described, potential regulatory elements have not yet been reported. Glucocorticoids $[10,33]$ and TNF- $\alpha$ [3] up-regulate mRNA levels for $20 \mathrm{~S}$ proteasome subunits. By contrast, the expression of $\alpha$ and $\beta$ subunits is not down-regulated by insulin [22].

There is also growing evidence that changes in levels of subunit mRNAs of the $19 \mathrm{~S}$ complex that binds to the $20 \mathrm{~S}$ proteasome to form the $26 \mathrm{~S}$ proteasome (figure 2) occur in various proteolytic conditions in skeletal muscle. However, the expression of ATPase and non-ATPase subunits of the $19 \mathrm{~S}$ complex is regulated independently of the expression of $20 \mathrm{~S}$ proteasome subunits, and clearly depends on a given catabolic state [3]. Furthermore, the mRNA levels and protein contents of the individual regulatory subunits are regulated independently, and do not always correlate with rates of protein breakdown [3]. These data are similar to the observations of Dawson et al. [11] in abdominal intersegmental muscles of Manduca sexta during programmed cell death. These authors reported a dramatic increase in the expression of the ATPase subunit MS73. However, western blot analyses showed increases in several ATPases including MS73, MSS1 and mts2, but not TBP1. Since ATPases provide energy for the assembly of the $26 \mathrm{~S}$ proteasome and for the breakdown of ubiquitin-conjugates, such adaptations may facilitate increased proteolysis. However, the specific changes in subunit expression and/or protein content that are crucial for altered proteolytic activities have not yet been identified. 
The 11S regulator (or PA28) also associates with the $20 \mathrm{~S}$ proteasome (figure 2) and stimulates its peptidase activities, without affecting the breakdown of proteins [9]. This hexamer is composed of two different subunits $\alpha$ and $\beta$. Bovine PA28 modulated the peptidase activities of the lobster muscle proteasome [32]. A small but reproducible increase in mRNA levels for both subunits of the 11S regulator was observed in unweighted muscles [3], suggesting that the PA28 particle played a role in muscle wasting. This complex may be involved in the final breakdown of peptides arising from proteolysis and/or in the degradation of some abundant endogenous muscle peptides (e.g. anserine and carnosine). However, the significance of these observations remains unclear. In other catabolic conditions such as cancer, no change in the mRNA levels for subunits of the $11 \mathrm{~S}$ regulator was observed [3].

\section{UBIQUITIN-PROTEASOME PROTEOLYSIS IN HUMAN DISEASES}

To determine whether mechanisms of proteolysis observed in animal models of cachexia are active in human diseases is an obvious clinical goal. Mansoor et al. [26] reported enhanced rates of whole-body protein breakdown and of 3-methylhistidine urinary excretion (an index of myofibrillar proteolysis) in head trauma patients compared with healthy volunteers. Increased mRNA levels for ubiquitin, 14$\mathrm{kDa} E 2$, and the $20 \mathrm{~S}$ proteasome subunits $\mathrm{HC} 2$ and $\mathrm{HC} 8$ were observed in muscle biopsies from these head trauma patients. Similar observations were also made in muscle biopsies from septic [43] and cachectic cancer patients (Rallière et al., unpublished observations). Thus, the ubiquitin-proteasome pathway could play an important role in some human conditions of acute muscle wasting (table III).

By contrast, no significant variation in mRNA levels for ubiquitin, 14-kDa E2, proteasome subunits, and other proteolytic genes was observed in chronic muscle wasting (table III). The lack of detectable activation of proteolytic genes in patients with Duchenne muscular dystrophy [8] and Cushing's syndrome [35] may result from the very progressive loss of myofibrillar proteins that prevails in such diseases. Alternatively, adaptative mechanisms may prevent increased expression of

Table III. mRNA levels for components of the ubiquitin-proteasome pathway in skeletal muscle from patients with wasting disorders.

\begin{tabular}{lccc}
\hline & \multicolumn{3}{c}{ mRNA levels } \\
\cline { 2 - 4 } Wasting condition & Ubiquitin & $14-\mathrm{kDa} 2 *$ & $\begin{array}{c}20 S \text { proteasome } \\
\text { subunits }\end{array}$ \\
\hline
\end{tabular}

Acute wasting

Head trauma

Sepsis

Chronic wasting

Muscular dystrophy

Cushing's syndrome increased

increased

$$
\begin{gathered}
\text { increased } \\
\text { nd }
\end{gathered}
$$

unchanged

unchanged increased

increased

Mansoor et al. [26]

Tiao et al. [43]

${ }^{*} 14-\mathrm{kDa} \mathrm{E} 2,14-\mathrm{kDa}$ ubiquitin conjugating enzyme; ${ }^{* *}$ nd, not determined. 
proteolytic genes, to avoid excessive and rapid muscle wasting. These hypotheses must be confirmed by further experiments in chronic situations of muscle wasting. It is noteworthy, however, that no change in the expression of proteasome subunits occurred in the atrophying muscles from interleukin-6 transgenic mice [44].

\section{POSSIBLE APPROACHES TO PREVENT MUSCLE WASTING}

Muscle wasting is advantageous during the initial phase of pathological states, since protein mobilization provides amino acids for energy metabolism and the synthesis of acute phase proteins. However, skeletal muscle is primarily involved in locomotion and respiratory effort. Thus, sustained muscle wasting has a very negative impact upon survival and/or rehabilitation of the organism in various instances of cachexia. For example, it is well known that the effectiveness of either radiotherapy or chemotherapy is strongly reduced in cachectic cancer patients. The discovery that the ubiquitin-proteasome pathway plays a major role in muscle wasting has lead recently to the emergence of new therapeutical approaches to counteract increased muscle proteolysis.

One strategy was to suppress the direct and/or indirect effects of catabolic factors responsible for the activation of the ubiquitin-proteasome pathway. For example, an anti-TNF- $\alpha$ treatment in tumor-bearing rats [24], and the administration of the glucocorticoid receptor antagonist RU 38486 in septic rats [42] blunted the increased ubiquitin expression in skeletal muscle. Unfortunately these compounds cannot be used easily in humans. AntiTNF- $\alpha$ antibodies are prohibitively expensive, and clinical trials with RU 38486 (which was primarily used for its abortion-inducing properties) have been recently stopped. In order to circumvent such problems others have recently tried using pentoxifylline, a very low-cost drug that blocks TNF- $\alpha$ production and is well tolerated in humans even at high doses. In these studies, treatment of Yoshida sarcoma-bearing rats with pentoxifylline or torbafylline (another xanthine derivative more potent than pentoxifylline) almost suppressed the cachexia, by inhibiting the activation of the ubiquitin-proteasome pathway [3]. Finally, the recent development of specific inhibitors of the proteasome and of ubiquitin conjugation [29] conceivably could lead to the design of future anti-cachectic therapies. However, this approach is not straightforward, because the ubiquitin-proteasome pathway is involved in many other essential processes such as cell proliferation, antigen presentation and the processing of transcription factors [9].

\section{CONCLUDING REMARKS}

The ubiquitin-proteasome system is now recognized as a major proteolytic pathway in skeletal muscle. Research in the immediate future will no doubt concentrate on the identification of proteins that are ubiquitylated, on the development of new techniques for measuring proteolytic activities of the proteasome, and on the elucidation of the signalling pathway of nutrients, hormones and cytokines that may directly or indirectly regulate this pathway in skeletal muscle. All these approaches should be useful for both the manipulation of muscle protein mass, and the development of new therapies for cachectic patients.

\section{ACKNOWLEDGEMENTS}

This work was supported by grants from the Conseil Régional d'Auvergne, Hoechst Germany, the Institut national de la recherche agronomique (Inra), and the Ministère de 
l'Education nationale, de la recherche et de la technologie (MENRT). Lydie Combaret and Thomas Tilignac were supported by Ph.D. fellowships from the MENRT, and Anthony Kee was supported by a post-doctoral fellowship from Inra.

\section{REFERENCES}

[1] Attaix D., Taillandier D., The critical role of the ubiquitin-proteasome pathway in muscle wasting in comparison to lysosomal and $\mathrm{Ca}^{2+}$ dependent systems, in: Rivett A.J. (Ed.), Intracellular Protein Degradation, JAI Press Inc., Greenwich, CT, USA, 1998, Adv. Mol. Cell. Biol. 27 (in press).

[2] Attaix D., Taillandier D., Temparis S., Larbaud D., Aurousseau E., Combaret L., Voisin L., Regulation of ATP-ubiquitin-dependent proteolysis in muscle wasting, Reprod. Nutr. Dev. 34 (1994) 583-597.

[3] Attaix D., Taillandier D., Combaret L., Rallière C., Larbaud D., Aurousseau E., Tanaka K., Expression of subunits of the $19 S$ complex and of the PA28 activator in rat skeletal muscle, Mol. Biol. Rep. 24 (1997) 95-98.

[4] Auclair D., Garrel D.R., Zerouala A.C., Ferland L.H., Activation of the ubiquitin pathway in rat skeletal muscle by catabolic doses of glucocorticoids, Am. J. Physiol. 272 (1997) C1007-C1016.

[5] Bailey J.L., Wang W., England B.K., Price S.R., Ding X., Mitch W.E., The acidosis of chronic renal failure activates muscle proteolysis in rats by augmenting transcription of genes encoding proteins of the ATP-dependent ubiquitin-proteasome pathway, J. Clin. Invest. 97 (1996) 1447-1453.

[6] Baracos V.E., DeVivo C., Hoyle D.H.R., Goldberg A.L., Activation of the ATP-ubiquitin-proteasome pathway in skeletal muscle of cachectic rats bearing a hepatoma, Am. J. Physiol. 268 (1995) E996-E1006.

[7] Baumeister W., Walz J., Zuihl F., Seemüller E., The proteasome: paradigm of a self-compartmentalizing protease, Cell 92 (1998) $367-380$.

[8] Combaret L., Taillandier D., Voisin L., Samuels S.E., Boespflug-Tanguy O., Attaix D., No alteration in gene expression of components of the ubiquitin-proteasome proteolytic pathway in dystrophin-deficient muscles, FEBS Lett. 393 (1996) 292-296.

[9] Coux O., Tanaka K., Goldberg A.L., Structure and functions of the $20 \mathrm{~S}$ and $26 \mathrm{~S}$ proteasomes, Annu. Rev. Biochem. 65 (1996) 801-847.
[10] Dardevet D., Sornet C., Taillandier D., Savary I., Attaix D., Grizard J., Sensitivity and protein turnover response to glucorticoids are different in skeletal muscle from adult and old rats. Lack of regulation of the ubiquitinproteasome proteolytic pathway in aging, $\mathrm{J}$. Clin. Invest. 96 (1995) 2113-2119.

[11] Dawson S.P., Arnold J.E., Mayer N.J., Reynolds S.E., Billett M.A., Gordon C., Colleaux L., Kloetzel P.M., Tanaka K., Mayer R.J., Developmental changes of the $26 \mathrm{~S}$ proteasome in abdominal intersegmental muscles of Manduca sexta during programmed cell death, J. Biol. Chem. 270 (1995) 1850-1858.

[12] Deveraux Q., Ustrell V., Pickart C., Rechsteiner M., A 26 S protease subunit that binds ubiquitin conjugates, J. Biol. Chem. 269 (1994) 7059-7061.

[13] Fagan J.M., Waxman L., A novel ATPrequiring protease from skeletal muscle that hydrolyzes non-ubiquitinated proteins, J. Biol. Chem. 264 (1989) 17868-17872.

[14] Fang C., Tiao G., James H., Ogle C., Fischer J.E., Hasselgren P.O., Burn injury stimulates multiple proteolytic pathways in skeletal muscle, including the ubiquitin-energy-dependent pathway, J. Am. Coll. Surg. 180 (1995) 161-170.

[15] Furuno K., Goodman M.N., Goldberg A.L., Role of different proteolytic systems in the degradation of muscle proteins during denervation atrophy, J. Biol. Chem. 265 (1990) 8550-8557.

[16] Gonen H., Stancovski I., Shkedy D., Hadari T., Bercovich B., Bengal E., Mesilati S., AbuAtoum O., Schwartz A.L., Ciechanover A., Isolation, characterization, and partial purification of a novel ubiquitin-protein ligase, $\mathrm{E}_{3}$, J. Biol. Chem. 271 (1996) 302-310.

[17] Haas A.L., Rose I.A., The mechanism of ubiquitin activating enzyme. A kinetic and equilibrium analysis, J. Biol. Chem. 257 (1982) 10329-10337.

[18] Haas A.L., Siepmann T.J., Pathways of ubiquitin conjugation, FASEB J. 11 (1997) 1257-1268.

[19] Handley P.M., Mueckler M., Siegel N.R., Ciechanover A., Schwartz A.L., Molecular cloning, sequence, and tissue distribution of the human ubiquitin-activating enzyme E1, Proc. Natl. Acad. Sci. USA 88 (1991) 258-262.

[20] Hershko A., Ciechanover A., The ubiquitin system for protein degradation, Annu. Rev. Biochem. 61 (1992) 761-807.

[21] Hobler S.C., Tiao G., Fischer J.E., Monaco J., Hasselgren P.O., Sepsis-induced increase in muscle proteolysis is blocked by specific pro- 
teasome inhibitors, Am. J. Physiol. 274 (1998) R30-R37.

[22] Larbaud D., Debras E., Taillandier D., Samuels S.E., Temparis S., Champredon C., Grizard J., Attaix D., Euglycemic hyperinsulinemia and hyperaminoacidemia decrease skeletal muscle ubiquitin mRNA in goats, Am. J. Physiol. 271 (1996) E505-E512.

[23] Llovera M., Garcia-Martinez C., Agell N., Marzabal M., Lopez-Soriano F.J., Argiles J.M., Ubiquitin gene expression is increased in skeletal muscle of tumour-bearing rats, FEBS Lett. 338 (1994) 311-318.

[24] Llovera M., Carbo N., Garcia-Martinez C., Costelli P., Tessitore L., Baccino F.M., Agell N., Bagby G.J., Lopez-Soriano F.J., Argiles J.M., Anti-TNF treatment reverts increased muscle ubiquitin gene expression in tumourbearing rats, Biochem. Biophys. Res. Commun. 221 (1996) 653-655.

[25] Lowell B.B., Ruderman N.B., Goodman M.N., Evidence that lysosomes are not involved in the degradation of myofibrillar proteins in rat skeletal muscle, Biochem. J. 234 (1986) 237-240.

[26] Mansoor O., Beaufrère B., Boirie Y., Rallière C., Taillandier D., Aurousseau E., Schoeffler P., Arnal M., Attaix D., Increased mRNA levels for components of the lysosomal, $\mathrm{Ca}^{2+}$-activated and ATP-ubiquitindependent proteolytic pathways in skeletal muscle from head trauma patients, Proc. Natl. Acad. Sci. USA 93 (1996) 2714-2718.

[27] Medina R., Wing S.S., Haas A., Goldberg A.L., Activation of the ubiquitin-ATP-dependent proteolytic system in skeletal muscle during fasting and denervation atrophy, Biomed. Biochim. Acta 50 (1991) 347-356.

[28] Medina R., Wing S.S., Goldberg A.L., Increase in levels of polyubiquitin and proteasome mRNA in skeletal muscle during starvation and denervation atrophy, Biochem. J. 307 (1995) 631-637.

[29] Mitch W.E., Goldberg A.L., Mechanisms of muscle wasting. The role of the ubiquitinproteasome pathway, N. Engl. J. Med. 335 (1996) 1897-1905.

[30] Mitch W.E., Medina R., Grieber S., May R.C., England B.K., Price S.R., Bailey J.L., Goldberg A.L., Metabolic acidosis stimulates muscle protein degradation by activating the adenosine triphosphate-dependent pathway involving ubiquitin and proteasomes, J. Clin. Invest. 93 (1994) 2127-2133.

[31] Mykles D.L., Lobster muscle proteasome and the degradation of myofibrillar proteins, Enzyme Protein 47 (1993) 220-231.

[32] Mykles D.L., Differential effects of bovine PA28 on six peptidase activities of the lobster muscle proteasome (multicatalytic pro- teinase), Arch. Biochem. Biophys. 325 (1996) $77-81$

[33] Price S.R., England B.K., Bailey J.L., Van Vreede K., Mitch W.E., Acidosis and glucocorticoids concomitantly increase ubiquitin and proteasome subunit mRNA levels in rat muscles, Am. J. Physiol. 267 (1994) C955-C960.

[34] Price S.R., Bailey J.L., Wang X., Jurkovitz C., England B.K., Ding X., Phillips L.S., Mitch W.E., Muscle wasting in insulinopenic rats results from activation of the ATP-dependent, ubiquitin-proteasome proteolytic pathway by a mechanism including gene transcription, J. Clin. Invest. 98 (1996) 1703-1708.

[35] Rallière C., Tauveron I., Taillandier D., Guy L., Boiteux J.-P., Giraud B., Attaix D. Thiéblot P., Glucocorticoids do not regulate the expression of proteolytic genes in skeletal muscle from Cushing's syndrome patients J. Clin. Endocrinol. Metab. 82 (1997) 3161-3164.

[36] Roberts R.G., Redfern C.P.F., Goodship T.H.J., Changes in the expression of proteolytic enzymes following correction of acidosis in humans with renal failure, in: Abstract Book of the 4th International Symposium on Amino Acid/Protein Metabolism in Health and Disease, Padova, Italy, 12-13 April 1996, Abstract 1

[37] Samuels S.E., Taillandier D., Aurousseau E., Cherel Y., Le Maho Y., Arnal M., Attaix D., Gastrointestinal tract protein synthesis and mRNA levels for proteolytic systems in adult fasted rats, Am. J. Physiol. 271 (1996) E232-E238.

[38] Taillandier D., Aurousseau E., Meynial-Denis D., Béchet D., Ferrara M., Cottin P., Ducastaing A., Bigard X., Guezennec C.-Y., Schmid H.-P., Attaix D., Coordinate activation of lysosomal, $\mathrm{Ca}^{2+}$-activated and ATPubiquitin-dependent proteinases in the unweighted rat soleus muscle, Biochem. J. 316 (1996) 65-72.

[39] Tawa N.E. Jr, Odessey R., Goldberg A.L., Inhibitors of the proteasome reduce the accelerated proteolysis in atrophying rat skeletal muscles, J. Clin. Invest. 100 (1997) 197-203.

[40] Temparis S., Asensi M., Taillandier D., Aurousseau E., Larbaud D., Obled A., Béchet D., Ferrara M., Estrela J.M., Attaix D., Increased ATP-ubiquitin-dependent proteolysis in skeletal muscles of tumor-bearing rats, Cancer Res. 54 (1994) 5568-5573.

[41] Tiao G., Fagan J.M., Samuels N., James J.H., Hudson K., Lieberman M., Fischer J.E., Hasselgren P.O., Sepsis stimulates nonlysosomal, energy-dependent proteolysis and increases ubiquitin mRNA levels in rat skele- 
tal muscle, J. Clin. Invest. 94 (1994) 2255-2264.

[42] Tiao G., Fagan J.M., Roegner V., Lieberman M., Wang J.J., Fischer J.E., Hasselgren P.O., Energy-ubiquitin-dependent muscle proteolysis during sepsis is regulated by glucocorticoids, J. Clin. Invest. 97 (1996) 339-348.

[43] Tiao G., Hobler S., Wang J.J., Meyer T.A., Luchette F.A., Fischer J.E., Hasselgren P.O., Sepsis is associated with increased mRNAs of the ubiquitin-proteasome proteolytic pathway in human skeletal muscle, J. Clin. Invest. 99 (1997) 163-168.

[44] Tsujinaka T., Fujita J., Ebisui C., Yano M., Kominami E., Suzuki K., Tanaka K., Katsume A., Ohsugi Y., Shiosaki H., Monden M., Interleukin 6 receptor antibody inhibits muscle atrophy and modulates proteolytic systems in interleukin 6 transgenic mice, J. Clin. Invest. 97 (1996) 244-249.

[45] Voisin L., Breuillé D., Combaret L., Pouyet C., Taillandier D., Aurousseau E., Obled C., Attaix D., Muscle wasting in a rat model of long lasting sepsis results from the activation of lysosomal, $\mathrm{Ca}^{2+}$-activated and ubiquitin- proteasome proteolytic pathways, J. Clin. Invest. 97 (1996) 1610-1617.

[46] Waterlow J.C., Garlick P.J., Millward D.J., Protein Turnover in Mammalian Tissues and in the Whole Body, Elsevier North Holland, Amsterdam, 1978.

[47] Wing S.S., Goldberg A.L., Glucocorticoids activate the ATP-ubiquitin-dependent proteolytic system in skeletal muscle during fasting, Am. J. Physiol. 264 (1993) E668-E676.

[48] Wing S.S., Banville D., 14-kDa ubiquitinconjugating enzyme: structure of the rat gene and regulation upon fasting and by insulin, Am. J. Physiol. 267 (1994) E39-E48.

[49] Wing S.S., Bedard N., Insulin-like growth factor I stimulates degradation of a mRNA transcript encoding the $14 \mathrm{kDa}$ ubiquitin-conjugating enzyme, Biochem. J. 319 (1996) 455-461.

[50] Wing S.S., Haas A.L., Goldberg A.L., Increase in ubiquitin-protein conjugates concomitant with the increase in proteolysis in rat skeletal muscle during starvation and atrophy denervation, Biochem. J. 307 (1995) 639-645. 